\title{
Existing levee system economic evaluation methodology
}

\author{
Edouard Durand ${ }^{1, a}$, Yann Deniaud ${ }^{2}$ and Sébastien Patouillard ${ }^{3}$ \\ ${ }^{1}$ Cerema Normandie Centre, Agence de Blois, 11 rue Laplace, CS 32912, 41029 Blois Cedex, France \\ ${ }^{2}$ Cerema Risques Eau Mer, Technopôle Brest Iroise, 155 rue Pierre Bouguer, BP 5, 29280 Plouzané, France \\ ${ }^{3}$ DREAL Centre-Val de Loire, 5, avenue Buffon - CS 96407, 45064 Orléans Cedex 2, France
}

\begin{abstract}
In France but also in other countries, levee system network are mostly composed of old levees, modified and reinforced during the past. In France, these systems, as road network, are considered as properties and financially as assets. Then the French Centre for Studies and Expertise on Risks, Environment, Mobility, and Urban and Country Planning (CEREMA) and Centre- Val de Loire Regional Direction of Environment Planning and Housing (DREAL) conducted a reflection to build a methodology for an economic evaluation of a levee system. This reflection is inspired by methodology based on asset replacement cost with a potentially depreciation reserve and methodology based on total economic value that takes into account benefits or provided services rendered by this asset. Therefore, the global economic value of a levee system is an average of structural cost balanced out with depreciation or bonus factors. The article details how structural cost is obtained with a levee system segmentation in homogeneous levee sections and unit prices and how depreciation or bonus are evaluated. Finally, this article discuss this methodology and its applicability on Loire levee systems with an example on Orléans levee system.
\end{abstract}

\section{Introduction}

In France, levee systems, just like road or other linear infrastructure networks, are considered as properties and financially as assets. To be taken into consideration in public accounts, the French Accounts Court (Cour des Comptes, 2016) demanded that an economic evaluation of such structures be performed (RNCE, 2016). Then the French Centre for Studies and Expertise on Risks, Environment, Mobility, and Urban and Country Planning (CEREMA) and Centre- Val de Loire Regional Direction of Environment Planning and Housing (DREAL) conducted an exploratory work on economic evaluation methodologies to lay the foundations for a reflection on methods for levee systems economic evaluation.

The purpose of this article is to review conditions of levee economic evaluation, to propose a calculation methodology and then to discuss its applicability on the River Loire's levee system.

\section{Levee economic evaluation conditions}

\subsection{Economic evaluation methodologies of tangible real estate assets}

Economic evaluation methodologies of tangible real estate assets are based on two value types: on the one hand, "exchange value" or "market value" with a price that can be obtained on a marketplace or determined by costs calculation and on the other hand "use value" corresponding to profits or future economic advantages rendered by asset usage [6].

Then, we can distinguished two types of evaluation methodologies: those based on asset replacement cost, eventually depreciated and those based on expected advantages or rendered services evaluation. For that, the Total Economic Value (TEV) of the asset has to be determined (Pearce et al., 2006).

\subsection{Levees economic evaluation particularities}

For levee systems and big linear infrastructures, venal value (market value) and use value are clearly distinct and their evaluations are complex. As levees are not classic goods, their venal value cannot be evaluated by simple prices analysis. This value has to be calculated with costs. Then, methodology based on depreciated replacement costs seems to be the only practical methodology. By the way, in France this methodology is recommended for roads, highways and dams (DEF, 2016).

Practical application of this methodology requires deep knowledge of levee structural components, of their conditions and maintenance or reparation costs to determine global cost of a levee system and then evaluate its replacement cost. Bonus and drop in value can be applied on the entire levee system regarding its use value 
or partially on certain components regarding local levee sections performance or regarding their historical patrimonial value. It becomes then essential and a prerequisite to have a fine assessment of levee system in term of main structures, components, functions and performance.

Use value of a levee system is first of all linked to its flood protection function. Therefore, this value is directly linked to the global value of protected goods or properties for a maximal expected level of performance of the levee system. However, levees could have secondary functions which values can also be important and complex to appreciate (roads in levee crest, agricultural, recreational, environmental ...functions). Levee systems could also have a high patrimonial value in historical sites and be classified as UNESCO World Heritage like Loire Valley. The Figure 1 illustrates the different components of total economic value (TEV) applied to levee cases.

The combination of all these use values make difficult the evaluation of levee systems economic value. Nevertheless, this evaluation can take advantage of damages costs analysis in protected areas often realized for financing demands in national action programs (French Big Rivers programs, PAPI...).

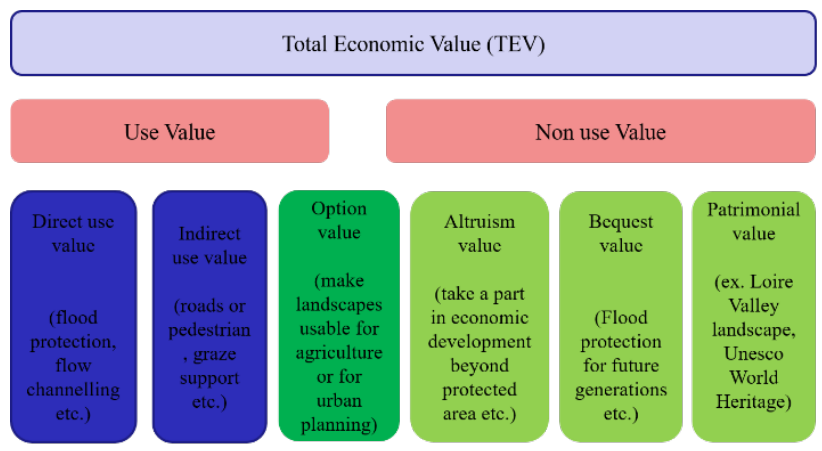

Figure 1. Total Economic Value for a Loire Levee system (Cerema after [7])

Regarding above elements, the methodology proposed for levee system economic evaluation is based on the combination of (i) replacement cost of asset, eventually globally or partially depreciated, (ii) evaluation of some assessable rendered services or expected advantages that could be part of total economic value (TEV) of this asset.

\section{Levee system economic evaluation methodology}

In France, there are more than $9000 \mathrm{~km}$ of flood protection levees in fluvial, torrential or coastal environments. State levees represent about $10 \%$ of this length but often protect main issues. These state levees are very old earthen levees (sometimes Middle Ages levees), heterogeneous because they were often made wider, increased, repaired, reinforced since they were built. That is typically the case for Loire levee systems with a total length of $700 \mathrm{~km}$ managed by local Territories Departmental Directions with the concourse of DREAL Centre Val de Loire. We built and illustrate the following methodology on these levees, very well documented.

\subsection{Typology of state levees}

Forms of existing old levees and their heterogeneous structures result in successive rebuilding and raisings following each historical flood events. Historical levees are mainly alluvial (sand, silt and clay) earthen embankments protected or reinforced with masonry components (stone made revetments, quays, walls, low walls...), containing overflow design structures like spillways and specific civil works structures to manage water flows (culverts, sluice gates...).

Thus, a levee system can be considered as a succession of "homogenous" segments, more or less long, interrupted by singular civil works or culverts. Each segment contains an historical embankment earthen core reinforced or not with different components or simply widened or increased with another embankment material. Therefore, a structural and functional study of the levee system can easily give the system separation in "homogenous" segments and specific works (Figure 2).

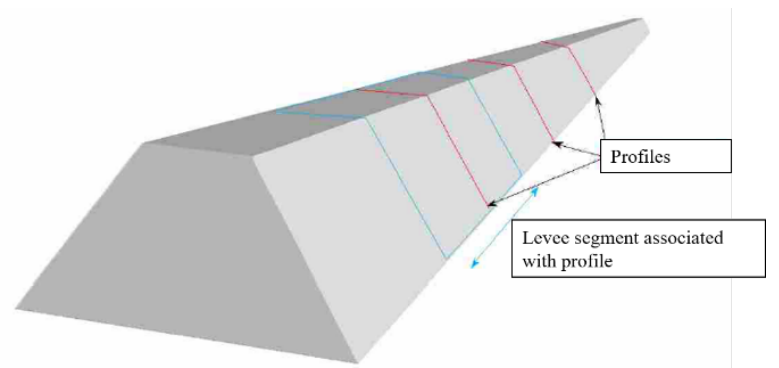

Figure 2. Description of the levee system separation in representative levee segments and profiles (Durand E., 2016)

We describe each levee segment with a representative topographic profile (Figure 3) composed by a core, structural (wall, spillways...) or functional components (drainage system, roads...) or reinforcement ones (thickening fill, riprap, cutoff wall...). The knowledge of unit prices (linear, surface or volumetric) of these components enables to evaluate economic value of the profile then segment and finally the entire levee system value.

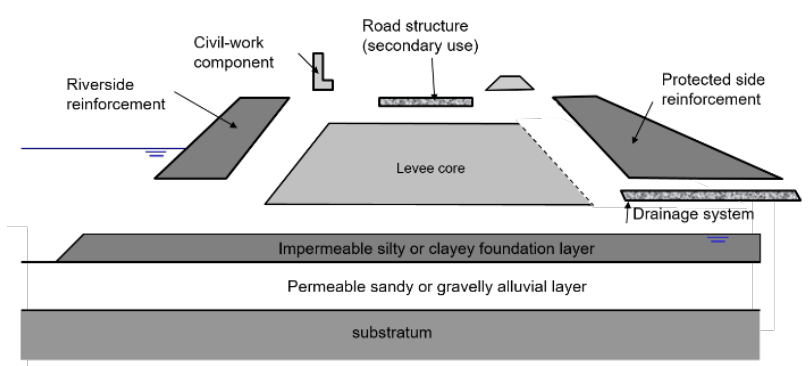

Figure 3. Levee segment separation in unit structural, functional or reinforcement components (Cerema)

\subsection{Calculation methodology description}

Calculation methodology is based on hypothesis that levee system global economic value is obtained by weighting "structural value" with depreciative coefficients related to functional levee state or with bonus coefficients related to patrimonial or use value (or rendered services). Then, the methodology consists in multiplying average 
levee system structural cost (including its current components), $\mathrm{C}_{\mathrm{s}}$, by weighting coefficients $\mathrm{Ki}$. The following Equation (1) gives the weighted global economic value $\mathrm{C}$ :

$$
C=C_{s} . K 1 . K 2 . K 3 \ldots . . K n
$$

With:

$C_{s}$ : average structural cost of the levee system, $K 1$ : coefficient related to actual levee performance, $K 2$ : coefficient of provided service related to prevented damages, $K 3$ : coefficient related to patrimonial value of levee system, $K n$ : others coefficient that could be added.

Levee system economic structural evaluation Cs based on levee segments separation in unit structural, functional and reinforcement's components (see figures 2 and 3 ) can be obtained with following formula:

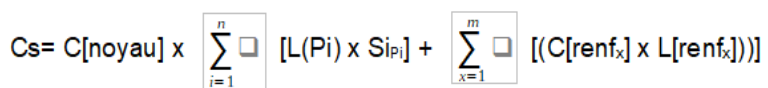

$$
\begin{aligned}
& +\sum_{y=1}^{p} \square C[\text { [Ouvy] }
\end{aligned}
$$

With:

C[noyau] the average volumetric cost of levee embankment; Pi the profile number representative of a levee length $\mathrm{L} ; \mathrm{n}$ the total number of profiles on the levee system; Sipi the trapezium surface of levee core Pi profile; $\mathrm{x}$ the reinforcement type with a unit linear cost $\mathrm{C}\left[\mathrm{renf}_{\mathrm{x}}\right]$ and present on $\mathrm{L}\left[\mathrm{renf}_{\mathrm{x}}\right]$ length; $\left.\mathrm{C}_{\mathrm{O}} \mathrm{Ouv}_{\mathrm{y}}\right]$ the cost of a specific works (sluice gate, spillway...); $\mathrm{m}$ the number of reinforcement and $p$ the number of specific works existing on the levee system.

\subsection{Average volumetric cost of levee core}

Average volumetric cost calculation of levee core $\mathrm{C}$ [noyau] is function of its geometry and well knowledge of levelling works unit costs. If exact core geometry is unknown, unit trapezium surface $\mathrm{Vu}$ can be approximated easily with charts regarding levee height, crest widths and banks slopes (Figure 4).

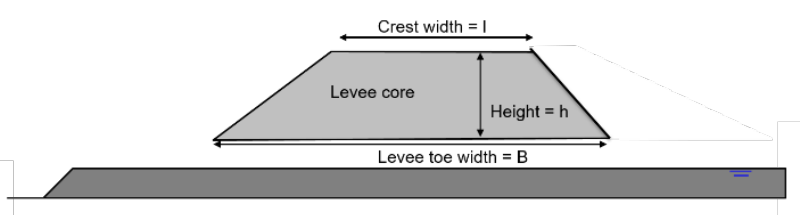

Figure 4. Trapezium built by embankment or levee core.

The unit volume $V u$ is given by :

$$
V u=[(B+l) \cdot h] / 2
$$

Several studies conducted from 2012 to 2014 indicate that average levelling works unit cost $\mathrm{Pu}$ is $13 €$ to $22 €$ [13] for 1 cubic meter of material extracted, brought on site and put in place. This cost is very dependent on material availability next to the working site. Then, to evaluate levee core building cost C[noyau] you just have to multiply unit volumes $\mathrm{Vu}$ by unit costs $\mathrm{Pu}$ as follow:

$$
C[\text { noyau }]=P u \cdot V u
$$

Charts or tables, function of levee height, bank slopes and crest width can rapidly be obtained to get unit cost of trapezoidal levee core section construction. Table 1 is an example for a unit price of levelling work of $20 € / \mathrm{m}^{3}$. Same principle is applied to get unit volumes and costs of widening reinforcements if such reinforcement exist on levee system (see Figure 3).

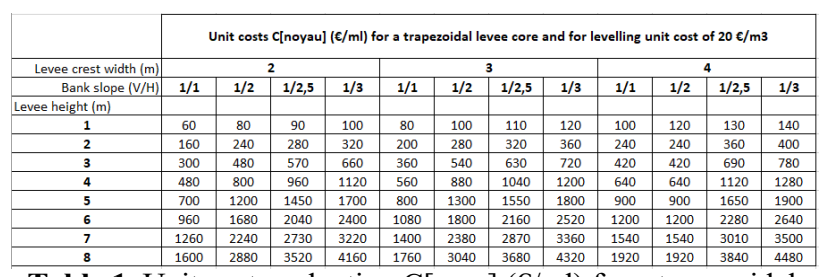

Table 1. Unit cost evaluation $C$ [core] $(€ / \mathrm{ml})$ for a trapezoidal levee function of its height, bank slopes and crest width.

\subsection{Costs of surface levee protective coatings}

Generally, fluvial or coastal flood protection levees own protective coating that is grass cover as a minimum. We find in literature an average unit price of $1 € / \mathrm{m}^{2}$ for a simple grass cover. For a masonry protective coating, unit prices are very dependent with quarry proximity and local labor cost. As a first approach we choose a unit price of

\begin{tabular}{|c|c|c|c|c|}
\hline \multirow[b]{2}{*}{ Bank slope $(\mathrm{V} / \mathrm{H})$} & \multicolumn{4}{|c|}{$\begin{array}{c}\text { Unit Surfaces Si }\left(\mathrm{m}^{2} / \mathrm{ml}\right) \text { of trapezoidal levee } \\
\text { bank }\end{array}$} \\
\hline & $1 / 1$ & $1 / 2$ & $1 / 2,5$ & $1 / 3$ \\
\hline \multicolumn{5}{|l|}{ Levee height $(\mathrm{m})$} \\
\hline 1 & 1,4 & 2,2 & 2,8 & 3,2 \\
\hline 2 & 2,8 & 4,5 & 5,5 & 6,3 \\
\hline 3 & 4,2 & 6,7 & 8,3 & 9,5 \\
\hline 4 & 5,7 & 8,9 & 11,1 & 12,6 \\
\hline 5 & 7,1 & 11,2 & 13,8 & 15,8 \\
\hline 6 & 8,5 & 13,4 & 16,6 & 19,0 \\
\hline 7 & 9,9 & 15,7 & 19,4 & 22,1 \\
\hline 8 & 11,3 & 17,9 & 22,1 & 25,3 \\
\hline
\end{tabular}
$100 € / \mathrm{m}^{2}$ for masonry coatings construction. Unit surfaces of trapezoidal levee are given in Table 2 for different heights and slopes.

Table 2. Levee bank unit surfaces $\mathrm{SI}\left(\mathrm{m}^{2} / \mathrm{ml}\right)$ function of its height and bank slopes.

\subsection{Levee reinforcements costs}

There are several types of levee reinforcements. For historical levees such as Loire levees, it is impossible to know precisely, all kind of reinforcement put in place during centuries. Nonetheless, in this study we try to list main reinforcement types, which are: riverside levee widening, protected side widening with drainage system at the toe, sheet piling or soil-mixing cut-off wall, riverside ripraps. This non-exhaustive list can be completed to refine levee economic evaluation. Based on DREAL Centre Val de Loire 2010 to 2016 operational works, unit reinforcements prices $\mathrm{C}\left[\mathrm{renf}_{\mathrm{x}}\right]$ were obtained and are set in Table 3. 


\begin{tabular}{|c|c|c|}
\hline \multicolumn{2}{|r|}{ Type of works } & $\begin{array}{l}\text { Ratio ( } € \text { TTC/ml) } \\
2016 \text { value }\end{array}$ \\
\hline \multicolumn{2}{|c|}{ Quay wall Reinforcement ${ }^{1}$} & 26,000 \\
\hline \multicolumn{2}{|c|}{ Reinforcement de pied de levee ${ }^{1}$} & 865 \\
\hline \multirow{2}{*}{ Levee core reinforcement ${ }^{1}$} & Sheet piles cut-off wall & 2,600 \\
\hline & Soil mixing cut-off wall & 980 \\
\hline Widening reinforcement $^{2}$ & $\begin{array}{l}\text { Levelling with toe drainage system on protected } \\
\text { side and with impermeable soils on riverside }\end{array}$ & 570 \\
\hline \multirow{2}{*}{ Embedded houses traitment ${ }^{1}$} & with house purchasing & 3,850 \\
\hline & without house purchasing & 1,550 \\
\hline \multirow{3}{*}{$\begin{array}{l}\text { Masonry protective coating } \\
\text { repairs }^{3}\end{array}$} & Slope $2 / 1$ & 810 \\
\hline & Slope 3/2 & 650 \\
\hline & Slope 3/1 & 1150 \\
\hline
\end{tabular}

Table 3. Unit cost (€ TTC/ml) of principal reinforcements of Loire levees (DREAL Centre Val de Loire, 2016).

To get global reinforcement cost of a levee system, you just have to precise what reinforcement is present on which segments and on which length $\mathrm{L}\left[\mathrm{renf}_{\mathrm{x}}\right]$.

\subsection{Costs of specific civil engineering works}

Civil works components on levee systems generally enable flows management through levees. For example we can find sluice gates, see gates (Figure 5) or drying culverts installed in lowest topographic points of protected areas, naturel or artificial drainage channels.

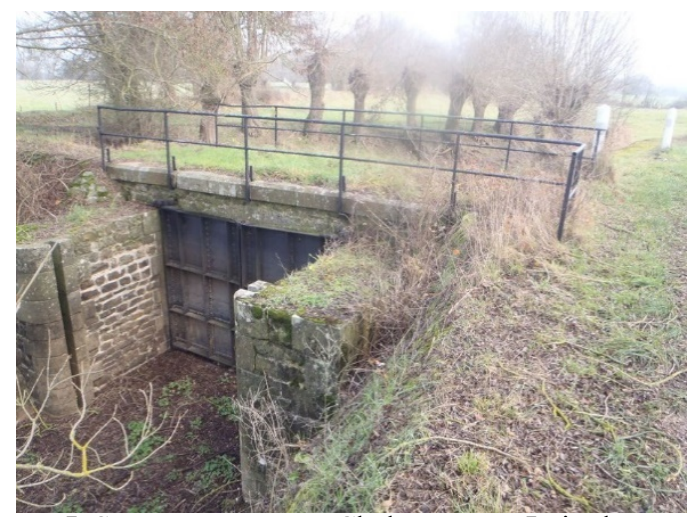

Figure 5. Seagate present on Chalonnes-sur-Loire levee system (CCerema)

More important structures like spillways or quays are also present on levees (Figure 6). Their costs, $\mathrm{C}\left[\mathrm{Ouv}_{\mathrm{y}}\right]$ in formula (2) must be case-by-case appreciated and no linear unit price can easily be determined.

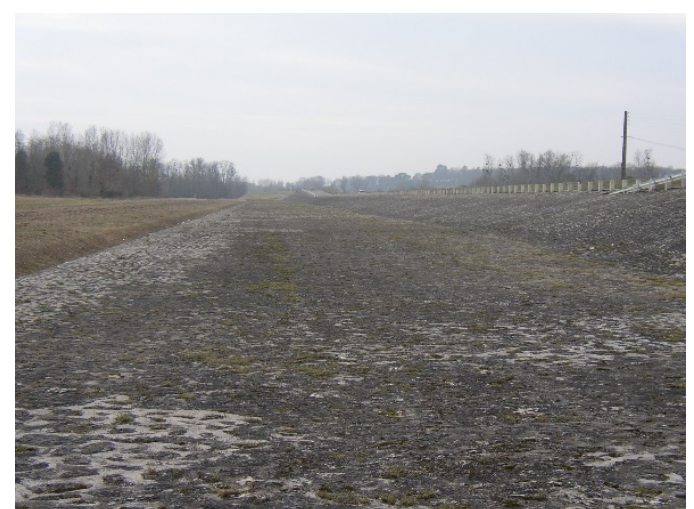

Figure 6. View of masonry downstream slope of spillway, near Blois, France (CE Durand).

\subsection{Costs of land property and supported structures}

In economic evaluation, land property that supports levee system is also taken into account with an average unit price $1 € / \mathrm{m}^{2}$. Levee width (see Figure 4) and if necessary constraints surfaces on both sides of levees enables to evaluate right of way surface. Furthermore, levees often support roads or other infrastructures on their crests [11] which represents an additional specific cost of economic levee evaluation.

\subsection{Evaluation tool to evaluate structural levee cost}

In order to facilitate economic structural cost evaluation of linear structures as levee systems, reinforced or not, with or without protective coatings, supporting roads or not, a spreadsheet can helpfully be used. With geometry data, even simplified ones, elementary surfaces, volumes and lengths can easily and automatically be calculated.

For central Loire levee systems, we naturally reused CARDigues tool [15] and adapted it to above presented methodology.

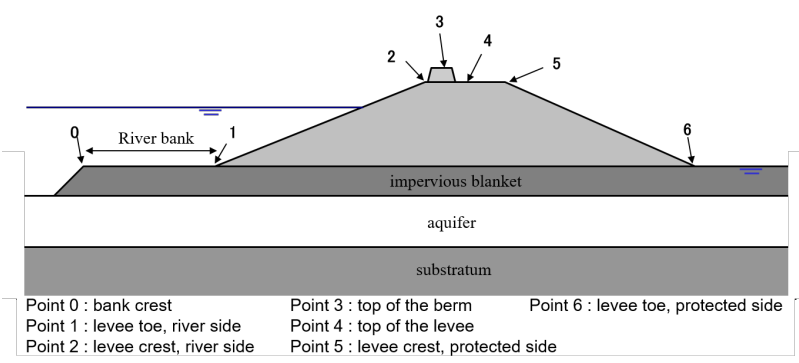

Figure 7. Characteristics of a typical profile used in CARDigue methodology [15]

Indeed, CARDigues tool was used on 46 Loire levees hazards studies and geometry data (shown on Figure 7) are already imput for each representative profile of levee segment, every $50 \mathrm{ml}$ length (generally). Presence and nature of reinforcements are also available data. We just added missing surface and volumetric calculations, and unit costs calculation defined above, based on unit prices fixed by user. Figure 12 is an extract of calculation tool filled with Orléans levee system data.

To this construction structural cost of levee and its reinforcements, we must add levee system specific components costs.

\subsection{Coastal levee's particularities}

For costal levee systems we can considered that it is composed with following elements: (i) earthen levees; (ii) natural works like dunes, beaches; (iii) civil-work structures (see wall, groynes etc.); (iv) hydraulic structures (culvert, see gates, sluice gates etc.). Differences with fluvial levee systems can be identified such nature or design of protective coating or reinforcements (rip rap, tetrapod...) but part of coastal levees segments are just sandy core levees with a grass coating (see Figure 8). 


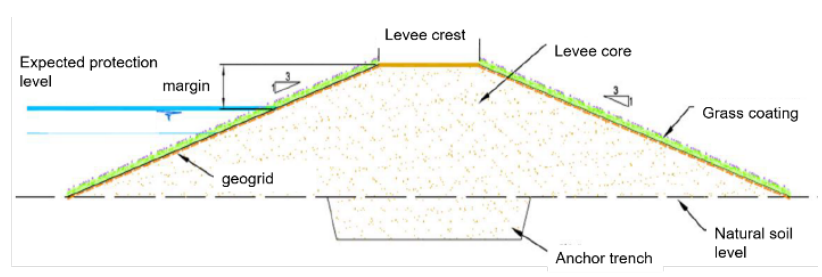

Figure 8. Typical profile of a coastal earthen levee of Somme's Bay, north of France [12]

Therefore, we have proposed to use the same methodology for coastal levee economic evaluation. For these systems, financial weight of specific civil-works will represent a most important part of total evaluation than fluvial levees.

\subsection{Weighting coefficients calculation}

In this methodology, we have suggested in formula (1) to introduce weighting coefficients for levee system global economic value.

The K1 coefficient is function of actual levee performance in comparison to expected performance. K1 expresses the difference between expected (or choosen) protection level, $\mathrm{N}_{\text {obj }}$, and the actual security level of the levee system, $\mathrm{N}_{\mathrm{s}}$. Both levels are defined in levee system hazards studies, required in French levee system regulations. We have proposed for $\mathrm{K} 1$ the following formula:

$$
K 1=1-\left(N_{o b j}-N_{s}\right) /\left(N_{o b j}-N_{\text {réf }}\right)
$$

with $\mathrm{N}_{\text {réf }}$ the riverside levee toe level i.e. level of first hydraulic charge on levee.

K2 coefficient represents rendered services regarding prevented damages during flood events. Economic analysis of infrastructures such as levee system in flooding areas are generally based on costs-benefits analysis $[8,14]$. In such studies the average annual damages (DMA), with or without levee system, is defined to evaluate average annual prevented damages (DEMA) due to levee system. We then have proposed for "use value" or rendered services value coefficient the following K2 definition:

$$
\begin{array}{r}
K 2=1+(D E M A) \\
/(D M A \text { without levee system })
\end{array}
$$

With:

DEMA $=($ DMA without levee system - DMA with levee system).

We have also add a K3 coefficient in methodology. It represents patrimonial value of levee system. Several levees are very old ones and own a specific value because systems interact on landscape morphology. It is the case for levees in Loire Valley classified as Unesco World heritage. Unfortunately, we have not find yet an easy way to define $\mathrm{K} 3$.

Other coefficients could be added later in methodology as knowledge on levee systems costs will increased.

\section{Loire levees: practical application}

The Middle Loire levee system is composed by 50 levees that protect 300000 inhabitants in potentially flooded areas. Between $\mathrm{XVI}^{\text {th }}$ and $\mathrm{XX}^{\text {th }}$ centuries, 3 or 4 big flood events occurred during each century and caused lot of breaches and damages. The last one was the 1907 flood event and the absence of any major flood event for more than 100 years is considered as a singularity and not as a decrease of hazard level. A huge flood event like in $\mathrm{XIX}^{\text {th }}$ century would cause huge damages evaluated to 8 billion Euros on river Loire basin.

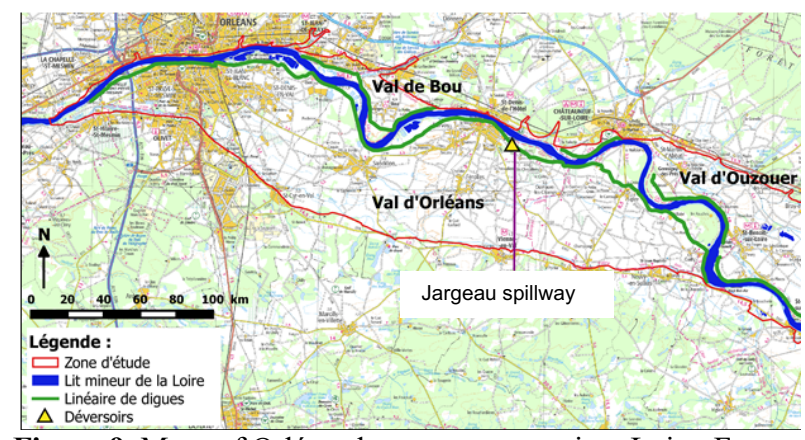

Figure 9. Maps of Orléans levee system on river Loire, France (Cerema -Source:Scan100®-IGN@)

Between 2012 and 2017, managers conducted 46 hazards studies on state levee Loire systems and safety levels $\mathrm{N}_{\mathrm{s}}$ were then defined. Maintenance and reinforcement recommendations were proposed to upgrade $\mathrm{N}_{\mathrm{s}}$. The 3 main levee systems on river Loire are Orléans (65 000 inhabitants and $44 \mathrm{~km}$ long), Tours (135000 inhabitants and $56 \mathrm{~km}$ long) and Authion (62 000 inhabitants and $80 \mathrm{~km}$ long). Orléans hazards study [10] was the first study on Loire levees and enables the development of methodology and CARDigues Tool used on other levee systems.

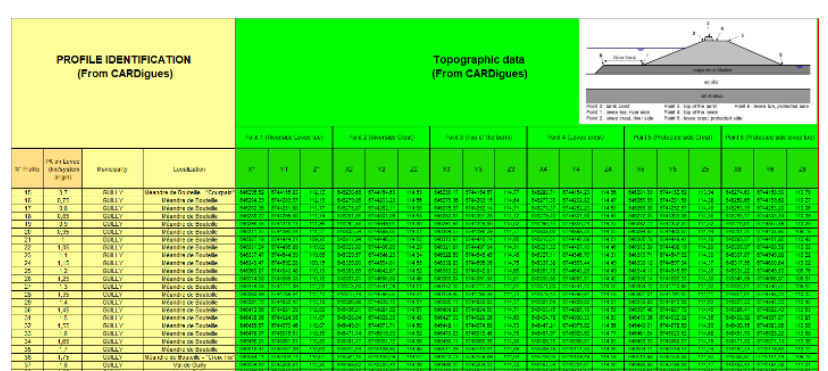

Figure 10. Extract of CARDigue Tool [15] - Profile geometry data.

Orléans levee system is $43,55 \mathrm{~km}$ long (see Figure 9). CARDigue's model of this system contains 872 profiles characterized by 7 specific points with $(\mathrm{X}, \mathrm{Y}$ and $\mathrm{Z})$ coordinates for each of them (cf. figures 7 and 10). Informations such civil-work structures, masonry wall, spillway and reinforcements are also data available in CARDigue (see Figure 11). Economic evaluation tool take this information and calculates, for each profile and for the entire system : levee embankment and core volumes, reinforcements volumes, bank slopes surfaces, right of way surface... 


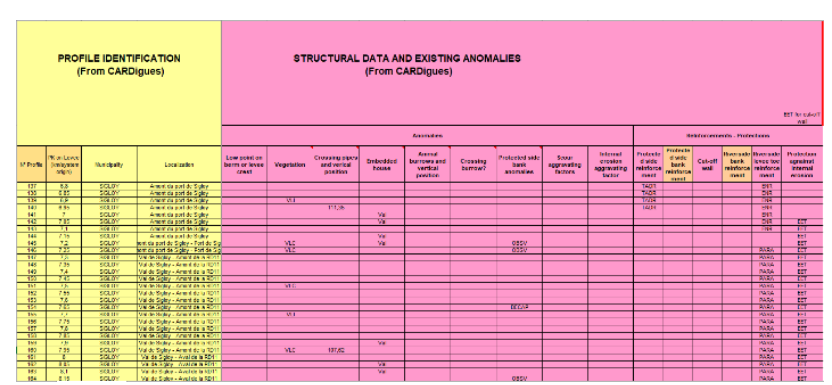

Figure 11. Extract of CARDigue Tool [15] - Profile structural and reinforcement data.

Then, for Orléans levee system we have following results: the volume of embankment is $4.1 \mathrm{Mm}^{3}$ (Millions of cubic meters) including $3.6 \mathrm{Mm}^{3}$ for core and $0,44 \mathrm{Mm}^{3}$ for protected side widening reinforcements and $0.06 \mathrm{Mm}^{3}$ for riverside ones. It contains $550 \mathrm{ml}$ of sheet piles cut-off wall and $7.45 \mathrm{~km}$ of soil-mixing cut-off wall. Total surface of riverside masonry protective coating is $490000 \mathrm{~m}^{2}$.

Based on unit prices shown in Figure 12, the structural value of Orléans levee system, without property value and without specific civil-work structures values (walls, spillways, roads...) is in first approach evaluated to $172 \mathrm{M} €$ (in 2016 Euro economic value). We then proposed to keep in mind a total structural value Cs of $200 \mathrm{M} €$ that is to say a structural value of $4600 € / \mathrm{ml}$ of levee.

\begin{tabular}{|c|c|c|c|c|c|c|c|}
\hline 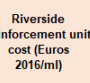 & 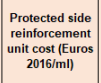 & 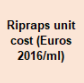 & 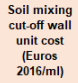 & $\begin{array}{l}\text { Shet pilling cut } \\
\text { off wal } \\
\text { (furs } 201\end{array}$ & 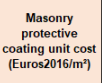 & 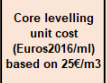 & \\
\hline 570,00 & 570,00 & 865,00 & 988,00 & 2600,00 & 100.,00 & 2063,00 & \\
\hline 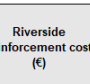 & 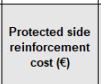 & pips cost & $\begin{array}{l}\text { ooil mixing } \\
\text { cuturof wall } \\
\text { cost (f) }\end{array}$ & $\begin{array}{l}\text { Sheet pilling cult- cut } \\
\text { off wal cost }(t)\end{array}$ & $\begin{array}{c}\text { Masony } \\
\text { proterive } \\
\text { cooting cost(f) }\end{array}$ & \begin{tabular}{|c|c|} 
Levee core cost \\
$|\theta|$
\end{tabular} & 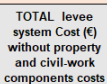 \\
\hline $3733500 €$ & $16159500 €$ & $3237000 €$ & $7301000 €$ & $1430000 €$ & $49017037 €$ & $90772000 €$ & $171700037 €$ \\
\hline $2 \%$ & $9 \%$ & $2 \%$ & $4 \%$ & $1 \%$ & $29 \%$ & $53 \%$ & $100 \%$ \\
\hline
\end{tabular}

Figure 12. Extract of structural levee system cost calculation tool adapted from CARDigues tool and applied on Orléans system [15]

On this levee system, safety level Ns was defined as the level of the flood of 70 years return period i.e. $4.67 \mathrm{~m}$ (95.15 m NGF) at Orléans hydraulic gauging station [10]. Reference level Nréf is defined at 3.75 m (94.22 m NGF) and corresponds to a 20 years' return period flood. The expected protection level $\mathrm{N}_{\mathrm{obj}}$ corresponds to a 200 years return period flood i.e. $5.77 \mathrm{~m}(96.25 \mathrm{~m} \mathrm{NGF})$.

With these elements and according to formula (5), K1 coefficient for Orléans levee system is equal to 0.455 regarding its actual performance. It represents a depreciative coefficient of $45,5 \%$ of its actual structural value. We can noticed that future operational works planned on this system will increased safety level Ns to $5.34 \mathrm{~m}$ (100 years return period flood event) and then K1 will be equal to 0.578 .

For Orléans valley the DMA without levee system was established to 6.6 M€. With actual levee system (Ns based on 70 years return period), the DMA is equal to $6.25 \mathrm{ME}$. Then, average annual prevent damages DEMA is the equal to $0.35 \mathrm{M} €$.
$\mathrm{K} 2$ coefficient, according to formula (6) is equal to 1.053 for Orléans levee system. It represents a $5.3 \%$ bonus of levee system according to our methodology. With future operations, DEMA will be $0.60 \mathrm{M} €$ i.e. K2 equal to 1.09 .

Then, for Orléans levee system, the global economic evaluation Corléans, according to formula (1) is equal to Corléans $=200 \times 0,455 \times 1,053=96 \mathrm{M} €$. With future operational works, this value will be $115 \mathrm{M} €$.

We just like to remind to readers that this is an estimation of levee economic evaluation based on a new methodology that needs to be refined and more largely tested on other levee systems to be approved.

\section{Conclusions}

A new methodology for levee systems economic evaluation was developed by Cerema and DREAL CentreVal de Loire and presented in this article. This methodology consists in a levee global evaluation using average structural costs of levee construction, weighted with different bonus or depreciative coefficients.

Average structural cost is obtained using unit costs, levee geometry and reinforcements components. Firstly applied on Orléans levee system, along river Loire in France, this methodology gives first results for levee economic evaluation. It will be tested on 46 others river Loire levee systems to make this methodology and weighting coefficients more accurate.

\section{References}

1. Stelling, G. S., and S. P. A. Duinmeijer (2003). A staggered conservative scheme for every froude number in rapidly varied shallow water flows, Int. J. Numer. Methods Fluids, 43(12), 1329-1354, doi:10.1002/ fld.537

2. Cour des comptes (2016) - Certification des comptes de l'État de 2015 - Observation d'audit (Art. R143-8 CJF) 3.1-03. Incertitude sur l'exhaustivité et l'évaluation des actifs comptabilisés au titre des digues contrôlées par l'État. Cour des comptes, 31 mars $2016,7 p$.

3. Fiche navette 2015-3.1-17 adressée par la Cour des comptes à la DREAL Centre. $8 \mathrm{p}$.

4. Direction de l'économie et des finances (DEF, 2016). Recueil des normes comptables de l'État, novembre 2016, $310 p$.

5. Recueil des normes comptables de l'Etat (RNCE, 2016)- Norme 6 Immobilisations corporelles (https://www.economie.gouv.fr/cnocp)

6. Bottazzi D., Roux J-F. (2012). Évaluation des actifs corporels. Cabinet Roux, présentation $17 p$.

7. BRGM/RP-63859-FR (2015) - Caractérisation des bénéfices économiques liés à la préservation des eaux souterraines - Le Cas des zones de sauvegarde pour l'alimentation en eau potable.

8. Pearce D., Atkinson G., Mourato S. (2006). Analyse coûts-bénéfices et environnement. Développements récents. Rapport OCDE, $351 \mathrm{p}$. 
9. Barnay, A., Calba G. (1968). Combien vaut votre entreprise ? Paris, Entreprise Moderne d'Edition, $1968,252 \mathrm{p}$.

10. Maurin J. et al (2012). Etudes de dangers des digues de classe A de la Loire moyenne et de ses affluents Levées du Val d'Orléans. Rapport DREAL Centre

11. Rapport d'étude Cerema «DREAL Centre Val de Loire - Rôles et impacts des rehausses des levées de Loire sur la sécurité routière - Cas du Val de CisseVouvray » Affaire C15RB0050 / E, juin 2016.

12. Rapport d'étude Artelia Eau \& Environnement «Syndicat Mixte Baie de Somme Grand Littoral Picard - PAPI Bresle Somme Authie - ANNEXE I Processus de décision pour les opérations structurelles et définition des systèmes de protection », Dossier 8420078/C - avril 2015.

13. Synthèse nationales des chantiers de terrassements 2006 à 2014, Sétra (Cerema/DtecITM)

14. CGDD. Analyse multicritère des projets de prévention des inondations - Guide méthodologique 2018. Collection Thema, mars 2018, $166 \mathrm{p}$.

15. Durand E., Maurin J., Bridoux B., Boulay A., Bontemps A. (2016) - River Loire levees hazard studies - CARDigues' model principles and utilization examples on Blois levees. International Conference FloodRisk2016, Lyon 